\title{
Towards a right-to-development governance in Africa
}

\author{
Carol C. Ngang \\ Department of Public Law, Faculty of Law, University of Pretoria, Hatfield Campus, Pretoria, South Africa \\ Carol.Ngang@up.za.ac
}

\begin{abstract}
In this article, I provide the rationale for conceptualizing a rights-based development model for Africa, necessitated by the conviction to seek African solutions to African problems. For the first time since independence, Africa has formulated a consolidated roadmap for development named "Agenda 2063," which looks promising and attainable but leaves unanswered questions relating to the right to development enshrined in the African Charter and ancillary treaty instruments. In retrospect, I illustrate how the right to development originated and has evolved in Africa, potentially setting the pace for development and human rights protection but has not yet recorded significant impact. I contend that Africa's development future is attainable only through a self-reliant consciousness, not by letting the development agenda be shaped by imported paradigms. I justify why and how this is achievable by advancing arguments in favor of right-to-development governance as a homegrown model for development in Africa.
\end{abstract}

\section{Introduction}

Over half a century after independence, Africa remains burdened with a myriad of developmental challenges that apparently stand in defiance of individual state efforts towards development. The African Union (AU) has thus adopted a consolidated roadmap for development entitled "Agenda 2063: The future we want for Africa" that provides a comprehensive policy framework for the continent for the next 50 years. The goal is to harmonize national and regional development efforts in order to achieve inclusive growth and sustainable development through optimal use of the continent's resources to the benefit of the African peoples (African Union Commission [AUC] 2015: 2-3).

Envisaging that development in Africa is achievable only through "self-reliance" and the "self-determination" of the African peoples, the agenda sets seven timebound standard aspirations and milestones; fulfilling them will require the meaningful participation of African peoples in transforming the continent (AUC 2015: 2-10). As promising as it appears, the agenda leaves unanswered questions relating to the right to development enshrined in the African Charter and ancillary treaties, which impose legally binding obligations on states parties to ensure its realization.

The continent of Africa is indeed made up of 54 sovereign states, which under the Organisation of African Unity (OAU) exercise absolute autonomy. That status quo has progressively dissipated, giving way to a more integrated AU that aims to achieve greater unity and solidarity, political and socioeconomic integration, and the promotion and protection of human rights and sustainable development (AU Constitutive Act 2000: Art. 3). In this article, references to "Africa" as a single entity are informed both by the AU Constitutive Act and, most importantly, by Agenda 2063 (AUC 2015: para. 20), which envisions a United Africa. 
It is important to also clarify that development is a broad concept that has often narrowly been understood predominantly from an economic growth perspective. This article however, approaches the subject from a human rights point of view: The right to development is increasingly recognized (within both human rights and development scholarship) as constitutive of a rights-based approach to development (see Kirchmeier 2006: 8-11; Kindornay, Ron, and Carpenter 2012: 476-485; UN Common Understanding 2003). The provision on the right to development in the African Charter (Organisation for African Unity [OAU] 1981: art. 22) guarantees that

1. All peoples shall have the right to their economic, social and cultural development with due regard to their freedom and identity and in the equal enjoyment of the common heritage of mankind.

2. States shall have the duty, individually or collectively, to ensure the exercise of the right to development.

Despite this legal recognition, the question that has not adequately been explored is how such an entitlement could be used to achieve Africa's development prospects. This article moves beyond the prevailing understanding of the right to development as simply a justiciable entitlement claimable by peoples against the state to make the argument that the right to development in Africa has the potential to be conceptualized as a development model.

The New Partnership for Africa's Development (NEPAD 2015: 1) recognizes that in order to pave the way for sustainable development in Africa, avoiding the blunders of the past is crucial. I argue that because independence in Africa was haphazardly achieved, countries within the continent have not anchored their development strategies on a sustainable model that reflects African realities. Overcoming this operational model deficit is one of the central challenges facing the continent. While Article 22 of the African Charter entitles the peoples of Africa to freely and self-reliantly make their own development choices, implementation remains a challenge, necessitating a rethinking of the model for achieving that vision.

I contend that Africa's development future is only attainable through a collective self-reliant consciousness: The continental agenda for development must not be thwarted by external influences or shaped by imported paradigms. To develop this argument, I proceed to trace the origins of the right to development. I then explore how the concept has evolved within Africa. Ultimately, I make the case for right-to-development governance as a homegrown model for development in Africa.

\section{Genesis of the right to development in Africa}

Although the right to development has been part of international debate on human rights for over half a century, mainstream scholarship ignores the African origins of the concept (Dabrowska 2010: 2-3). A comprehensive understanding of the right to development, I argue, requires knowledge about the events that gave birth to such a right. As Kirchmeier, Lüke, and Kalla (2008: 7) point out, Africa's underdevelopment is integrally linked to exploitation by industrialized countries.

Yet, the origin of the right to development has been attributed consistently to Eleanor Roosevelt, who is said to have argued prior to the adoption of the Universal Declaration of Human Rights that "we will have to bear in mind that we are writing a bill of rights for the world and one of the most important rights is the opportunity for development" (see Sengupta 2000: 554-555; Alston 1988: 5-6). Other narratives also attribute the origin of the right to development to provisions of international human rights treaties, which are interpreted to imply the right to development. ${ }^{1}$ Though these interpretations may not be wrong, they are misleading in the sense that they muddle clarity on the African origins of the right to development.

As Cornwall and Nyamu-Musembi (2004: 1420) rightly observe, many of the principles central to the right to development have been integral to struggles for self-determination, which predate the discourse on human rights. Empirical studies further suggest that Africa's coerced involvement with industrialized countries under the colonial machinery explains part of the continent's current state of underdevelopment (Nunn 2008: 140). I argue that we must look back into history to determine the factors and circumstances that built up into a legitimate claim on the right to development. 


\section{A history of development injustices and the quest for independence}

Regardless of the level of contemporary governance challenges facing Africa, the negative and dehumanizing effects of slavery and colonialism on development across the continent cannot be ignored. For a period of over 500 years (from 1400 to 1900), the African continent experienced massive raids for slaves that led to the extraction of the continent's human potential, causing serious deterioration in patterns of economic and sociocultural development (Nunn 2007: 4). The inordinate demand and acquisition of slaves through warfare and kidnapping severely retarded progress in Africa (Nunn 2005: 4). There is empirical evidence of a direct connection between slavery and Africa's current state of underdevelopment: Countries from which the largest numbers of slaves were extracted have remained the least developed to this day (Nunn 2008: 140). Indeed, to use the term "slave trade" is itself misconceived because to say there was trade implies that Africa reaped corresponding benefits from the transactions, which in reality was not the case. Millions of Africans were bundled away for a surprisingly disparate exchange of firearms, gun powder, brandy, cloth, tobacco, glassware, and iron among other goods (Whatley and Gillezeau 2009: 6) - none of which contributed to the development of African societies, then or now.

Though we cannot be certain of how the continent would have fared in the absence of slavery, it cannot be denied that Africa would not have remained stagnant if the raid for slaves and subsequent colonization had not taken place. The era of slavery was followed by European colonization on the pretext that the African continent was backward and needed civilization (Nkrumah 1963: 8). Colonial rule in most of Africa, which lasted approximately 75 years, was anchored on a policy of sustained "immiserization" (Heldring and Robinson 2012: 10-17). Local populations were forced to comply with colonial rule and, in most of the colonies, the proportion of resources spent on "law and order far exceeded that spent on education, health, and social welfare combined" (Oloka-Onyango 1999: 172). Governance was based on the strategy of "divide and rule," which eventually created ethnic cleavages that have in most cases resulted in political instability, conflicts, and animosity and, thus, compromised development on the continent (Heldring and Robinson 2012: 20-21).

Some have argued that colonialism benefited Africa through increased income per capita and higher school enrollment, adult literacy, life expectancy rates, and corresponding increases in human capital (Prados de la Escosura 2011: 1-2); yet, these statistical changes have not resulted in overall increases in development. Heldring and Robinson (2012: 23) contend that the legacy of abuse and dispossession bequeathed by colonialism negates any optimistic interpretation of its impact on development in Africa. Apart from some isolated infrastructural projects such as railroads, forts, export systems, and a cash economy that were used principally to promote colonial interests (Hrituleac 2011: 14-15), evidence abounds that the peoples of Africa have experienced remarkable deterioration in living standards over time (Heldring and Robinson 2012: 10-15). Socioeconomic development remained a privilege that the colonial authorities exercised the discretion to grant to the African peoples (Oloka-Onyango 1999: 172).

Such development injustices ignited resentment, which eventually grew into the wave of liberation struggles that swept across the continent from the late 1950s onward. The quest for independence constituted the first steps towards asserting a moral entitlement to development, as Nkrumah made clear: "We have at least the right to ask [to be left] alone to work out our destiny in ways that seem most apposite to our circumstances and means" (1963: xv). The codification of international law, which recognizes the right to self-determination, legitimized the cause for decolonization. The adoption of international human rights instruments further guaranteed that justice could be achieved through the assertion of rights, which in turn informed the emerging argument that development in Africa could be claimed as a matter of right.

Yet, the persistence of human rights abuses and corresponding challenges to the well-being of African peoples in the decades since independence begs several questions: What did the countries of Africa envisage they would achieve by seeking to become independent from colonial domination? How was independence supposed to redress the wrongs of colonialism? Did protagonists in the liberation of Africa envisage a strategy to shape the future of the continent after independence? Africa's 
ongoing development challenges suggest that these questions might not have been taken seriously in the throes of struggles for independence.

\section{Operational model deficit and the postindependence challenge}

From its very foundation, countries involved in the struggle for independence across Africa faced challenges due to the lack of a functional development model. The charisma of the liberation leaders inspired hope that the timing was appropriate for decolonization. However, leadership alone could not constitute sufficient justification for seeking independence. Owing to the range of development injustices, it would have been rational to formulate a solemn proclamation as justification for rejecting colonial domination and also as a platform for reconstruction of the African continent. Such a proclamation would have provided the policy framework to proscribe further imperialistic tendencies and also to bind the political conscience of the would-be independent state governments from governance malpractices.

The African liberation leaders placed their emphasis instead on political freedom, as echoed by Nkrumah's rallying ideology to seek first the political kingdom with the anticipation that other things would eventually be added (Gassama 2008: 352). They underestimated the extent to which slavery and colonialism had undermined African societies and so engaged in the decolonization project emboldened by their "belief in the capacity of ordinary people to decide their own future through politics" (Gassama 2008: 345). These liberation leaders imagined, albeit wrongly, that political freedom would transform African societies. They failed to realize that many of the "ordinary people" had been dispossessed of the socioeconomic capacity to be able to engage meaningfully in the game of politics.

At independence, Africa needed a pragmatic model for human and social reconstruction rather than paradigms that simply sought to consolidate civil liberties and political freedoms. For instance, African human rights instruments provide for a range of fundamental human rights such as the right to life, the right to vote, the right to freedom of expression, and the right to movement among others. The realization of such rights, however, remains compromised by the inability of most people to sustain a decent livelihood. Because the liberation leaders craved political independence, their colonial masters shrewdly crafted succession plans in the form of independence constitutions with some loose fundamental rights, which gave the false hope that development would follow (Aguda 1989: 13).

Unfortunately, those constitutions bred chaos and instability by design, rather than ensuring national development. While Britain bequeathed presidential systems and written constitutions to its former African colonies, Britain itself remains governed by a parliamentary system and not through a written constitution (Go 2010: 111-112). Such manipulation sabotaged the independence project and in so doing created the opportunity for the colonial machinery to maintain its grip on the colonies. As African leaders became increasingly conscious that liberation meant much more than nominal political independence, they haphazardly fumbled with and in effect became divided over the question of political ideology and approaches to development. The likes of Kenyatta and Mobutu advocated for Western-style capitalism while Nyerere, Nkrumah, and Sekou Toure lobbied for African socialism. Irrespective of ideology, these new African regimes lacked the potential to protect the fragile states from neocolonial exploitation.

When Doudou Thiam advocated for a proclamation of the right to development for the Third World, it was indeed a call for the recognition of a new framework for development through which the priorities of developing countries could be articulated effectively. If industrialized countries rejected such a paradigm, the argument ran, that there was no reason why Africa could not contextualize its implementation. Though the struggle for liberation envisaged that Africa would be better in the hands of Africans than under colonial rule, events took a different turn. Instead of advancing human potential as the basis for consolidating independence, the leaders themselves sought to define the continent's political future amidst the complexity of domestic challenges and encroaching globalization (Gassama 2008: 334). Due to lack of foresight and misplaced priorities, these same leaders squandered crucial time that could have been invested in developing Africa, focusing instead on futile efforts to combat neocolonialism. 
Political instability and the internal conflicts that engulfed most of Africa after independence proved that the acquisition of political freedom without an effective framework for development was fatally wrong. Conscious of this fact, African governments quickly resorted to codifying laws to protect the African patrimony - a project that, in my opinion, should have taken place prior to independence. Nevertheless, the construction of the resulting legal framework was timely enough to create the minimum standards for the protection of Africa's development aspirations vis-à-vis the exploitative behavior of industrialized countries (see Borella 1971: 246) and, I argue, could offer the foundation for a right-to-development-based paradigm for governance.

If the struggle for and subsequent acquisition of independence had been anchored in the idea of a right to development, the probability of sustained development in Africa would have been much greater. The wording of the OAU Charter contains elements that could have been formulated to yield a more authoritative operational framework for the continent's development agenda rather than the weak framework that exists. Over half a century since the OAU was formed with the aim of harnessing the gains of independence to ensure the well-being of the African peoples, the continent remains vulnerable to exploitation. In the section that follows, I illustrate how the right to development has evolved in Africa, setting the pace and circumscribing the potential for development and human rights protection.

\section{Evolution of the concept of the right to development}

\section{Latent manifestations}

The idea of a right to development found latent manifestation in the right to self-determination and the campaign for a New International Economic Order (NIEO). By recognizing that colonized peoples were entitled to self-determination, the UN Charter (1945: art. 1[2]) established that colonialism was inconsistent with international law. The principle of self-determination thus provided the legitimate basis for decolonization, which eventually led to the liberation of most of Africa (Özden and Golay 2010: 1). It is established that the right to development emerged as an extension of the right to selfdetermination, which resulted in political independence (Anghie 2013: 66).

The campaign for the NIEO, which proceeded most independence struggles, was championed by the Group of 77 developing countries, the majority of which were African countries. This campaign aimed to further the cause for global equity and justice and to ensure the integration of decolonized states into the global system (Nagan 2013: 29). Though that aspiration never fully materialized, the struggle for the NIEO paved the way for the first public pronouncement on the right to development (Ouguergouz 2003: 298). Eventually, the Declaration on the Right to Development was adopted as a follow-up to the quest for an equitable global system, which is indeed alluded to as an important antecedent to the concept of the right to development. ${ }^{2}$

\section{Formal recognition and protection}

The conceptualization of the right to development happened through proclamations emanating from the African continent and subsequently through legal endorsement.

\section{Public proclamations}

Tribute has been paid to Senegalese Jurist Kéba M’baye for conceptualizing the idea of development as a human right, whereas earlier related statements precede M'baye's pronouncement. While addressing the Economic Conference of the Group of 77 in Algiers in 1967, Senegalese Minister of Foreign Affairs Doudou Thiam declared that " $\mathrm{t}]$ he old colonial past, of which the present is merely an extension, should be denounced" and in response states should "proclaim, loud and clear, the right to development for the nations of the Third World" (Ouguergouz 2003: 298). Thiam made clear that the right to development resulted from the injustices of colonial subjugation from which Africa deserved to be relinquished. 
In 1969, Cardinal Léon-Étienne Duval of Algiers also publicly advocated that "the right to development should be proclaimed for the Third World" and, by so stating, decried the development injustices perpetuated by industrialized countries (Ouguergouz 2003: 298). M'baye's proclamation, which gained widespread attention in academia and development politics, only came later in 1972 to provide clarity for understanding development as a legal entitlement. Precisely, he defined the right to development as a human right guaranteed to be enjoyed by everybody (M'baye 1972: 505). The exploitation that continued to happen in Africa even after independence underlined M'baye's formulation of the right to development, which he conceived as a human rights offense necessitating the application of the law. Later in 1981, while commissioning the group of legal experts to draft the African Charter, the thenPresident of Senegal Sedar Senghor stated that "[w]e want to lay emphasis on the right to development and other rights which need the solidarity of our states to be fully met" (ACHPR 2009a: para. 173).

These statements forcefully conveyed the understanding that Africa was unlikely to advance in a sustainable manner if it failed to uphold the idea of the right to development. By proclaiming the right to development, protagonists such as M'baye and Senghor were indeed postulating a development paradigm with the potential to drive Africa into a new era, though it had yet to be taken seriously. The independence leaders embraced political freedom with the anticipation that socioeconomic development would follow. If the right to development had been legally enshrined by that point, it would have in my opinion defined more coherently a sustainable model for Africa than the nominal independence that each of the African states achieved in isolation.

\section{Legal endorsement}

It is important to draw attention to the right-to-development dispensation that has been established in Africa through the extensive commitments undertaken in the range of declarations. Each of these imposes moral responsibility ${ }^{3}$ while a number of treaties also impose legally binding obligations on the right to development in Africa. To set the record straight with regard to initial official recognition, Mahalu's (2009: 19) claim that the right to development was first documented by the UN Commission on Human Rights in 1977 is misinformed: The right to development was indeed first officially given statutory recognition in the 1972 Constitution of Cameroon.

Over a decade later, the OAU proceeded to adopt the African Charter, which enshrines the right to development as a justiciable entitlement of the peoples of Africa. The charter has been ratified by all member states of the AU except South Sudan, implying that all states parties are legally enjoined to implement the right to development at the domestic level. Accordingly, a number of African countries have followed through with domestication and enshrined the right to development in their national constitutions. ${ }^{4}$ The AU went further in 2003 to adopt the Protocol on the Rights of Women, which also enshrined in its Article 19 the right to sustainable development for the women of Africa. This is a groundbreaking achievement for the predominantly patriarchal societies of many African countries, in which women have been largely suppressed through conservative practices. Another major milestone was achieved in 2006 with the adoption of the African Youth Charter, which enshrines in Article 10 the right to development for the generations of young people in Africa.

It is worth noting that the right to development in Africa is conceptualized with the realities of the continent's development challenges in mind. Hence, the legal protection it has acquired ensures that the obligations derived in conjunction with the right must be complied with, keeping these constraints in mind. In addition, the African Commission's nascent jurisprudence ${ }^{5}$ has helped to clarify the normative content and intricate dimensions of the right to development as a collective entitlement (Kamga 2011: 382). What, therefore, does it mean when we talk about the right to development in Africa?

\section{Conceptual clarity}

First and foremost, it is important to clarify that the right to development as it is formulated in the African Charter is not a solicitation for development assistance as it is envisaged at international level, that is, to be achieved through development cooperation (Sengupta 2003: 20). Rather, the right to development in Africa is fundamentally an assertion of socioeconomic and cultural self-determination. 
It is a subjective concept that, in as much as it is recognized universally as an inalienable human right, in its practical implementation remains relative to particular circumstances. In the African context, the right to development represents the collective potential of the African peoples to actively participate in the development process and to freely formulate policies that allow for human rights protection and for justice in development to prevail.

Article 22 of the African Charter requires states parties to make it possible for the peoples of Africa to exercise their right to development. This obligation entails creating the enabling environment and providing the opportunity to put the right to development effectively into practice. Contrary to Sengupta's (2002: 843) understanding that to have a right means to have a claim to something (which engenders a positive duty for the fulfillment of that claim), the right to development in Africa entails not only a positive expectation to achieve a certain material entitlement but also a negative duty to protect the right to development from contravention (Oduwole 2014: 3).

In effect, it represents the right to be allowed the freedom and the opportunity to advance beyond prevailing circumstances. Besides being a right in itself, the right to development provides the means through which the all-encompassing concept of development and the continuum of universally recognized human rights may simultaneously be achieved. A radical shift towards a rights-based approach to development is required in order to empower the peoples of Africa with the capabilities and freedoms to make their own development choices. This is explained by the fact that other development models have not demonstrated the potential to advance Africa in a comprehensive manner.

\section{Deficiency in imported development models}

By imported development models, I am referring to paradigms that have been borrowed and experimented with in Africa but have failed or proven inadequate in sustaining development and human rights protection on the continent (see Šlaus and Jacobs 2013: 1-4; NEPAD 2015: 5). I focus on two of these models - namely, World Bank structural adjustment programs (SAPs) and subsequent good governance requirements. Despite the failure of SAPs, African governments have nevertheless wholly embraced the good governance framework that followed it without sufficient consideration of its potential to derail development in Africa (as SAPs did).

Following the collapse of commodity prices and resulting economic crisis throughout Africa in the 1970s, the World Bank and the International Monatary Fund (IMF) seized the opportunity to introduce SAPs as a recovery program for Africa and a vehicle for promoting free market capitalism. The SAPs provided "conditional lending" to African countries (Thomson 2010: 197) on the condition that governments targeted for debt relief were obligated to adjust their economic policies in favor of trade liberalization and to privatize state-owned enterprises, to reduce public expenditures through salary cuts and retrenchments of public service functionaries, to close state marketing boards, to institute export-driven agricultural reforms, to impose currency devaluation, and to implement fiscal austerity measures (Heidhues and Obare 2011: 58; Dicklitch and Howard-Hassmann 2007: 325).

According to Dicklitch and Howard-Hassmann (2007: 325-327), the kind of macroeconomic policies that informed the SAPs were intended to release the productive capacity of the African peoples and thus stimulate economic growth, without which socioeconomic rights would not be achieved. Abouharb and Cingranelli (2007: 40) contend that respect for human rights instead constitutes the prerequisite for equitable economic growth, which means the SAPs could only have been achieved to the extent that human rights (particularly socioeconomic rights) were exercised and respected. In spite of the World Bank and the IMF's commitment to ensure that human rights are not violated in the course of their operations, implementation of the SAPs significantly infringed upon important economic and social rights (Abouharb and Cingranelli 2007: 40).

Dicklitch and Howard-Hassmann (2007: 327) cite Ghana and Uganda as success stories in the implementation of the SAPs, claiming that "when the state relinquishes control of the economy, private citizens will be more willing to save and invest" (Dicklitch and Howard-Hassmann 2007: 329). Yet, assessments subsequent to the imposition of SAPs show that instead of releasing the productive capacity of local peoples, these programs resulted in "overall economic failure" with "destructive social 
consequences" because they were never really intended to promote development in Africa (Logan 2015). Dismissing claims about the successful implementation of the SAPs in Ghana, Odutayo (2015) argues that such policies failed in their intended objectives (i.e., failed to alleviate poverty, to improve living conditions, or to promote economic growth by relieving indebtedness) instead creating the opportunity for the wanton exploitation of national resources and violation of the socioeconomic and cultural rights of the peoples.

In Uganda, structural adjustment took the form of trade liberalization and privatization, benefitting the government and corporate actors disproportionately more than it did to the Ugandan people (Kingston et al. 2011: 121). While the liberalization of cash crops benefited only the small number of Ugandan farmers who grew coffee (and, therefore, had quite minimal positive impact on rural income), privatized public enterprises were mostly purchased by foreign stakeholders rather than by the Ugandan people (Kingston, Irikana, Ndienye, and Kingston 2011: 121). Elsewhere in Africa, Rono (2002: 81-98) shows how in Kenya the implementation of the SAPs as a policy tool to accelerate economic growth instead resulted in "the marginalization of the poor in the distribution of educational and health benefits and a reduction in employment," principally because related programs were ill conceived, ignoring the realities of the existing social structures and aspects related to human development.

These examples illustrate the extent to which the SAPs not only failed but actually pushed African economies further into depression, with the associated socioeconomic hardships borne disproportionately by poor people, many of whom are still struggling to recover. Other imported models have equally failed in Africa, but, because of space constraints, they cannot be discussed here. However, they provide justification for the need for a homegrown model, which I propose could be conceptualized as right-todevelopment governance.

\section{Right-to-development governance}

Africa has indeed made one of the most significant contributions to the global dialogue on development and human rights by advancing the right to development and yet has failed to explore its transformative potential. As Rajagopal (2013: 893) rightly argues, the right to development was originally formulated to achieve a "fundamental transformation of global governance." Faced with prevailing economic imbalances perpetuated through global patterns that constrain developing countries by design, the question remains whether Africa is capable of overcoming the challenge (World Bank 2000: 7).

\section{Transformative potential}

The pursuit of unfettered economic growth has caused rising and seemingly insurmountable global inequalities (Šlaus and Jacob 2013: 1). This is particularly true for Africa, which continues to struggle to catch up with the accelerating pace of globalization. Building on the spread of rights-based approaches to development as alternatives to economic growth models (Melber 2012: 5-11), I argue in favor of the right to development as a governance paradigm for Africa, given the paradigm's double potential to uphold human rights and to promote justice in development.

As a model for advancing human rights, the right to development creates the opportunity for the realization of the continuum of human rights that otherwise may not be achieved in isolation. Where specific rights are not explicitly provided for, the right to development could be interpreted to establish the existence of such rights as the right to food, the right to housing, and the right to an adequate standard of living, among others. As a justiciable entitlement, the right to development in Africa requires legal accountability and thus protects against impunity. Because the right to development in Africa is a collective entitlement, litigating related violations could have wide-ranging transformative impact and could dramatically improve the human rights situation on the continent.

The right to development also provides a platform for justice in development, allowing for the realization of human rights while simultaneous pursuing economic growth objectives in an equitable manner. It gives priority to people-centered development programming and accordingly orients policy formulation, development planning, and corresponding modalities for integrated governance. 
Interestingly, Africa has pioneered and remains the pacesetter on the right to development, so an African development agenda ought to be informed largely by the right-to-development approach. Unfortunately, prevailing theories have often stood in direct opposition to effective action (Šlaus and Jacob 2013: 2-3).

Similar to the haphazard manner in which independence was achieved, the vision for a new Africa outlined in Agenda 2063 includes an ambitious program for development but fails to specify the applicable model for addressing concretely the issues at stake, particularly development injustices and human rights violations. Africa is burdened not only by a human development crisis but more crucially by a systemic crisis that requires an appropriate model. While the Agenda 2063 document makes mention of an "African approach to development and transformation" (AUC 2014: 20), it does not state what that approach is, nor does it envisage how to drive the development plan to effective realization.

The agenda emphasizes pan-Africanism and African cultural renaissance that, of course, are valuable political ideologies that reflect the vision for a new Africa. I submit that these ideologies need to be glued together by the concept of the right to development that undergirds the proposed operational model for a unique form of homegrown African development governance.

\section{Justification for the model}

I define the right-to-development governance in Africa as an integrated rights-based development model, grounded in (1) popular participation, (2) liberty of action in making development choices, (3) advancement of human capabilities for the sustainable management of Africa's resources, and (4) the propagation of the African identity and value systems within a legal framework that guarantees genuine accountability and equitable redistribution for the improved collective well-being of the African peoples.

The pervasiveness of low human-development indices throughout the region remains a major challenge despite significant gains in economic growth. To address it requires an indigenous development model such as right-to-development governance for dealing with the on-the-ground realities. While some of its constituent elements may not be entirely new, naming the concept as a homegrown model can significantly shape the manner in which development is conceived of and prioritized in terms of legal entitlement. The formulation of Agenda 2063 as an expression of political will on the part of African governments is commendable. Making clear that the realization of that agenda is owed to the peoples of Africa as a legal entitlement provided for by the African Charter is even more crucial.

The proposed model also imports conceptual ideas from good governance that despite its limitations has nevertheless facilitated improvement in political accountability, public sector reforms, and democratization yet lacks the potential to redress the range of development challenges in Africa because of its more institutional focus on the state as the machinery to drive development. Acknowledging the role of the state as both a duty bearer and holder of the right to development, I concur with Murray that "the construction of the state in Africa is an essential first, if not the most, important step in the transition to sustainable development" (2004: 242). However, it is illogical to prioritize the development of state institutions over human development and to expect to achieve people-centered sustainable development.

By proposing the right-to-development governance model as the basis for advancing human potential through policy and implementation strategies that respond to the lived realities of the majority of African peoples, I reframe development as an all-inclusive value system embodied in the concept of human rights. Development is not simply a means of pursuing a single value such as wealth (Nagan 2013: 24). Rather, the right-to-development governance model demonstrates the potential to redress Africa's development challenges by incorporating issues of socioeconomic and cultural development and political governance within development programming. This is underscored by the fact that a systemic change in Africa would entail capabilities development, institutional strengthening, structural innovation, economic growth, social transformation, and cultural reawakening, which can only be achieved by an emancipated and empowered people. 
My argument for right-to-development governance as a potential model for development and human rights protection in Africa rests on a number of assumptions. First, African governments have the legal obligation to ensure that the stage is set for development to be achieved as a matter of right guaranteed by the African Charter. Second, given deeply rooted corruption and weak governance on the continent, African governments have an equal duty to be accountable to their peoples. Third, the peoples of Africa are entitled to make their own development choices and to participate meaningfully in shaping the continent's development future. Fourth, given previous experiences, Africa needs a legal framework for development based on the rule of law to combat impunity. Fifth, African governments are enjoined, based on the right to self-determination and sovereign equality of states, to assert their autonomy against foreign domination. Finally, development gains should be equitably redistributed to ensure improved well-being for the African peoples.

If human development shortfalls indeed constitute Africa's major setback as highlighted by the African Charter for Popular Participation (African Union 1990: art. 6), then the countries in the region should pursue development models that prioritize human potential rather than models that consider African peoples only as objects to be used for the advancement of the state and the market economy. Africa requires a "development approach rooted in popular initiatives and self-reliant efforts," devoid of constraints and unwarranted external pressures (AUC 2014: 76-77). Right-to-development governance thus stands in sharp contrast to the prevailing good-governance model that is currently propagated in Africa.

\section{Problematizing good governance in Africa}

As discussed above, the majority of African governments have readily embraced the good-governance paradigm for development policymaking. Yet, this approach, as Maldonado (2010: 4) has noted, is a World Bank invention that came into use in the 1990s following the failure of SAPs. The central premise underlying the good-governance paradigm is that structural adjustment failed because of the incompetence of African governments in managing their economies. Good governance was thus introduced to enable African governments to remedy the failures by improving the "institutional performance" of the state as a condition for securing further loans from the World Bank (Maldonado: 2010: $5-10)$.

The focus on good governance is justified by the neoliberal conviction that "better governance promotes economic development" (Gisselquist 2012: 1-3). Yet, human development is unfortunately not included in this framework, thus raising concerns as to the relevance of such a model, which as Gisselquist contends is not a "useful concept for development analysts" (2012: 2). Though it emphasizes respect for human rights, the Lawyers' Committee for Human Rights (now Human Rights First) has argued that the "governance debate looks to human rights not for their intrinsic value but for their instrumental role in creating an environment in which effective and sustainable economic development can occur" (Lawyers Committee for Human Rights 1995: 61).

As stated earlier, good governance is more focused on improving the performance of the state than on advancing human capabilities, which remains a major concern in Africa. Based on the standards of the right to development that emphasize the achievement of outcomes as well as process as inherent rights, the right-to-development governance encourages meaningful participation and, therefore, places the power of development decision making in the hands of the people. By contrast, the good governance framework systematically excludes large segments of the African population from the development process.

Unlike good governance that approaches the African problem from a foreign perspective, often without cognizance of the real issues at stake, the right-to-development governance model envisages the formulation of appropriate development policies and implementation plans that are suited to African realities. Research conducted by Corrigan (2009: 8) on the review reports of six countries that have been through the NEPAD-coordinated African Peer Review Mechanism reveals that the central issues that need addressing in order to accelerate socioeconomic development for the achievement of sustainable development and poverty eradication in Africa include education, healthcare, water and 
sanitation, shelter and land redistribution as well as the promotion of gender equality. Democratization, political reforms and state institutional performance (which constitute good governance priority areas) are of little livelihood value to the millions of African peoples who do not have an education or a roof over their heads and cannot afford sufficient food (see Gauri and Brinks 2008: vii).

The right-to-development governance also envisages relieving Africa of dependency on development assistance and the associated debt burden and in turn compels African governments to explore domestic sources of economic potential. Africa is endowed with the resource potential to facilitate a sustainable management of the economy. Following the pan-African renaissance philosophy of African solutions to African problems, the right-to-development governance model has the potential for radical transformation and therefore, as a home-grown model, must first of all seek to deal with a number of challenges.

\section{Challenges to overcome}

According to Aguda, every African government that has concern for its people "must accord [priority to] the right to development in its governance of the country" (1989: 25). This has largely not been the case owing to the persistent abuse of state power by African leaders and endemic corruption across all sectors of African society, which remain the major causes of poverty and exclusion from the development process (Transparency International 2015). Article 22 of the African Charter imposes a legal obligation on states parties to individually or collectively ensure that the right to development is achieved. It obliges African governments to eliminate obstacles to development (United Nations DRTD 1986: art. 5), which include massive human rights violations and the political factors that hinder development.

Translated into the proposed right-to-development governance model, African governments are enjoined to create an enabling environment that is informed by the rule of law, democratic practice, and respect for human rights. As underscored in Aspiration 3 of Agenda 2063, the realization of the vision for transformation compels African governments (based on their obligations under the African Charter and the AU Convention on Preventing and Combating Corruption) to become serious about eliminating corruption, impunity, and the massive violation of human rights. The rule of law framework ensures that the peoples of African can hold the state legally responsible for ensuring democratic legitimacy.

\section{Operational considerations}

Implementing the right-to-development governance model involves four types of requirements: objective, conduct, process, and outcome. Objective requirements entail African peoples themselves meaningfully engaging with the state to define national development priorities. African governments must marshal the political will, in turn, to recognize the right to development as both a moral and a legal obligation that they owe to all the peoples of Africa. Objective requirements also entail the allocation of rights and liberties to the peoples of Africa, who in turn can assert their entitlement to socioeconomic and cultural development. The formulation of development policies must therefore fundamentally be informed by objective obligations of this sort.

The requirement of conduct defines the behavioral pattern of the state as duty bearer and the peoples as right holders. It structures relationships of transparency and accountability through which the state is enjoined to ensure that development is achieved without compromising the enjoyment of human rights. While the aspiration for a United Africa can only be achieved over the long term (AUC 2015: 4, para. 20), the requirement of conduct necessitates that in the meantime, domestic constitutional arrangements safeguard the right to development as a means for holding state governments to greater levels of responsiveness and accountability.

As mentioned earlier, many African countries have already enshrined the right to development as a domestic constitutional entitlement. While others have yet to incorporate the right to development as an integral part of domestic law, some constitutions do contain provisions that could be 
interpreted purposively to imply the right to development. The South African Constitution, for instance, does not enshrine the right to development per se, but as Gutto (2006: 109-118) argues, the right to development is indeed implied in the constitutional order. According to the obligation imposed by the African Charter to collectively ensure the realization of the right to development, other African countries are similarly enjoined to guarantee legal protection of the right to development at the domestic level.

Requirements of process necessitate the pursuit of people-centered and rights-based approaches to development, primarily because the fulfillment of human rights and human capabilities remain major challenges to development in Africa. Requirements of process entail forging a rule of law framework to enure that in the process of creating development, human rights are not violated. This is illustrated by the the case Centre for Minority Rights Development and others v. Kenya (hereafter referred to as the Endorois litigation) adjudicated by the African Commission, which established the precedent that development cannot be carried out in contravention of the right to development. The case dealt with the wrongful expropriation of communal land belonging to the Endorois peoples of Kenya.

The Endorois are a semi-nomadic indigenous community that for centuries has existed within a sustainable pastoral economy and practiced a cultural and religious lifestyle that intimately connects the community to its ancestral lands in the locality of Lake Bogoria. According to the Endorois' customary understanding of land ownership, they have claimed exclusive community entitlement to the land for habitation, cultural practices, and ancestral worship (ACHPR 2009b: paras. 72-73 and 87). In 1973, the Kenyan government arbitralily and forcibly removed the Endorois from the land in question to make way for a game reserve for the promotion of tourism. This resulted in disruptions in the community's pastoral economy as well as its collective well-being.

After several unsuccessful attempts to secure compensation or to seek redress in a domestic court, members of the Endorois community took the matter to the African Commission through the representative action of two international nongovernmental organizations (NGOs). The complainants alleged a series of violations, including of the right to development guaranteed by the African Charter. The litigation provided the African Commission the opportunity to clarify the intricate dimensions of the right to development, by which it established that the right to development does not imply dependency but is rather an emancipatory process that emphasizes the importance of choice and liberty of action for the achievement of well-being (ACHPR 2009b: para. 283; Sing'Oei 2013: 395).

Accordingly, the commission established that the Kenyan government had indeed violated the Endorois peoples' right to development (ACHPR 2009b: para. 298). The decision conveyed the fact that human well-being must precede economic growth or the welfare of the state economy, which the Kenyan government had prioritized over the livelihood of these indigenous peoples. Although restitution of the land in question and the payment of damages has not taken place as the commission ruled, the decision nevertheless has had a deterring effect and thus sets the precedence that colonial-style invasion and land grabbing (especially of indegous territories) is unlawful.

Finally, the requirement of specific forms of outcome is rooted in the principle of equitable redistribution. Outcome requirements ensure that specific material or abstract entitlements could be anticipated from the development process, either through policy reforms or through judicial procedures when a violation is confirmed. Article 22(1) of the African Charter requires that the gains from development be shared; hence, the peoples of Africa legitimately should be able to expect to enjoy on an equitable basis the communal resources pertaining to the African patrimony. Similarly, Agenda 2063 lays out the policy framework for implementation but unfortunately does not define the model for its realization.

\section{Conclusion}

Africa is sitting on a model that could replace obsolete concepts regarding national and global governance (Šlaus and Jacobs 2013: 4-5) and, in so doing, could help fulfill the global quest for innovative development models - yet its potential is unrealized. The fact that the right to development is already being propagated as "a development paradigm for a globalized future" (UN Human Rights 2013: 495) 
motivated my interest in determining to what extent this paradigm is viewed in the same light in Africa, taking into consideration its African origins and relevance to development on the continent. ${ }^{6}$

In providing an account of Africa's compromised development history, I argued that the quest for independence (which fundamentally aimed to give decolonized Africa new direction) was not anchored in a sustainable model for development. The independence project thus lacked a crucial strategy for complementing political independence with socioeconomic and cultural self-determination. Basing my arguments on an historical reading of the African origins of the right to development and also taking into account its transformative potential, I made the case for conceptualizing a right-todevelopment governance model that could ensure not only the realization of Africa's ambitious program for development (as envisaged by Agenda 2063) but also development with equity and justice through which human rights protection is assured.

As a homegrown concept formulated with the realities of Africa's development challenges in mind, the right-to-development governance model has the potential to respond to the socioeconomic and cultural issues that affect the entire continent. Compared to good governance, I have argued that the right-to-development governance model is human rights based and more people centered. It provides the basis for ensuring that in the process of creating development, issues relating to human rights and human capabilities development remain major concerns in Africa and are sufficiently addressed.

Within the context of global development politics, characterized by competing interests, it is important to ask whether Africa has an interest to protect - and whether that interest could be achieved by asserting the right to development? The evidence is overwhelming that Africa can make considerable advancement not only by asserting the right to development as a legal entitlement but also by giving more pragmatic meaning to the concept of right to development as a homegrown model for development rather than employing a universalized, imported discourse.

While the right to development in Africa remains a work-in-progress, particularly in terms of implementation, this article aims to shift the debate from the perspective of looking at the right solely as a claimable legal entitlement to reimagining it as a paradigm for development, as it was originally conceived. This article begs the need for further research to be able to explore its practical dimensions in shaping Africa's development future. Human rights and development theorists as well as policymakers and development stakeholders must not lose sight of the fact that as the world looks forward to embracing a new global paradigm for development, the need for such a pragmatic model is greater and even more relevant for Africa. The urgency of finding such a model explains why it is important to give the proposed right-to-development governance insightful consideration.

\section{Acknowledgments}

I owe profound gratitude to Dr. Solomon Tekle and Dr. Wanki Justin as well as the anonymous reviewers for their valuable comments on previous drafts of this article.

\section{Notes}

1. UN Charter (United Nations 1945: art. 55); UDHR (United Nations 1948: arts. 22 \& 25-28); ICESCR (United Nations 1966: art. 11[1]).

2. Declaration on the Right to Development. GA Res A/RES/41/128 1986, art. 3(3) (United Nations 1986).

3. African Union. (2007) preamble; United Nations (2007) arts. 21 \& 23; ACHPR. (2004a) preamble \& para. 1; ACHPR. (2004b) para. 6; ACHPR. (2003a) para. 3; NEPAD. (2001) para. 79; United Nations. (2000) paras. 11 \& 24; United Nations. (2001) para. 78; ACHPR. (1999) para. 2; United Nations. (1992) principle 3; United Nations. (1993) paras. I(10) \& 11; United Nations DRTD. (1986).

4. Constitution of the Republic of Malawi (1994: art. 30); Constitution of the Democratic Republic of Congo (2005: art. 58); Constitution of the Federal Democratic Republic of Ethiopia (1994: art. 43); Constitution of the Republic of Uganda (2006: objective 6 on Directive Principles); Cameroon's Constitution of 1972 with amendments through 2008, preamble, read together with art. 65.

5. ACHPR. (2009b) DRC case para. 95; ACHPR. (2009a) Endorois case.

6. OAU. (1981, June) African Charter on Human and Peoples' Rights preamble para. 4. 


\section{Notes on contributor}

Carol C. Ngang is an Academic Associate/Doctoral Researcher at the Department of Public Law, University of Pretoria.

\section{References}

ABOUHARB, M. Rodwan, and CINGRANELLI, David. (2007) Human Rights and Structural Adjustment (New York: Cambridge University Press).

AFRICAN COMMISSION ON HUMAN AND PEOPLES’ RIGHTS (ACHPR). (1999) Grand Bay Declaration and Plan of Action adopted at the 1st OAU Ministerial Conference on Human Rights, 12-16 April, Grand Bay, Mauritius.

AFRICAN COMMISSION ON HUMAN AND PEOPLES' RIGHTS (ACHPR). (2003a) Kigali Declaration adopted at the 1st African Union Ministerial Conference on Human Rights in Africa. AU Doc. MIN/CONF/ HRA/Decl.1 (1).

AFRICAN COMMISSION ON HUMAN AND PEOPLES' RIGHTS. (2003b) Protocol to the African Charter on the Rights of Women in Africa.

AFRICAN COMMISSION ON HUMAN AND PEOPLES' RIGHTS (ACHPR). (2004a) Pretoria Declaration on Economic, Social and Cultural Rights in Africa adopted by the African Commission at its 36th Session in December 2004.

AFRICAN COMMISSION ON HUMAN AND PEOPLES' RIGHTS. (2004b) Solemn Declaration on Gender Equality in Africa adopted at the 3rd Ordinary Session of our Assembly in Addis Ababa, Ethiopia, 6-8 July 2004.

AFRICAN COMMISSION ON HUMAN AND PEOPLES' RIGHTS (ACHPR). (2009a) Centre for Minority Rights Development and Minority Rights Group International on behalf of Endorois Welfare Council v Kenya Comm. 276/2003 (2009) AHRLR 75.

AFRICAN COMMISSION ON HUMAN AND PEOPLES' RIGHTS (ACHPR). (2009b) Democratic Republic of Congo $v$ Burundi, Rwanda \& Uganda Comm227/99 (2009) AHRLR 9.

AFRICAN COMMISSION ON HUMAN AND PEOPLES’ RIGHTS. (2009a, May) Kevin Mgwanga Gunme \& Others $v$ Cameroon (2009) AHRLR 9 (ACHPR 2009).

AFRICAN UNION. (1990, February) African Charter for Popular Participation in Development and Transformation.

AFRICAN UNION. (2000) Constitutive Act of the African Union.

AFRICAN UNION. (2007) African Charter on Democracy, Elections and Governance adopted during the 8th ordinary session of the Assembly of the African Union on 30 January 2007.

AFRICAN UNION COMMISSION. (2015, April) Agenda 2063: The Africa We Want (Addis Ababa: African Union).

AGUDA, Akinola. (1989) Human Rights and the Right to Development in Africa (Lagos: Nigerian Institute of International Affairs).

ALSTON, Philip. (1988) Making space for new human rights: The case of the right to development. Human Rights Yearbook, $1,1-40$.

ANGHIE, Anthony. (2013) Whose utopia?: Human rights, development, and the third world. Qui Parle: Critical Humanities and Social Sciences, 22(1), 63-80.

BORELLA, François. (1971) Le système juridique de l'Organisation de l'Unité Africaine. Annuaire Français De Droit International, 17(1), 233-253.

CONSTITUTION OF THE DEMOCRATIC REPUBLIC OF CONGO. (2005).

CONSTITUTION OF THE FEDERAL DEMOCRATIC REPUBLIC OF ETHIOPIA. (1994).

CONSTITUTION OF THE REPUBLIC OF CAMEROON OF 1972 WITH AMENDMENTS THROUGH 2008. (2008).

CONSTITUTION OF THE REPUBLIC OF MALAWI. (1994).

CONSTITUTION OF THE REPUBLIC OF UGANDA. (2006).

CORNWALL, Andrea, and NYAMU-MUSEMBI, Celestine. (2004) Putting the "rights-based approach" to development into perspective. Third World Quarterly, 25(8), 1415-1437.

CORRIGAN, Terence. (2009, May) Socio-Economic Problems Facing Africa: Insights from six APRM Country Review Reports. South African Institute for International Affairs - Occasional Paper No. 34.

DA_BROWSKA, Anna. (2010) Legal status of the right to development. Haskoli Island University, 1-11.

DICKLITCH, Susan, and HOWARD-HASSMANN, Rhoda. (2007) Public policy and economic rights in Ghana and Uganda. In Economic Rights: Conceptual, Measurement, and Policy Issue, Shareen Hertel and Lanse Minkler (eds.) (New York: Cambridge University Press).

GASSAMA, Ibrahim. (2008) Africa and the politics of destruction: A critical re-examination of neocolonialism and its consequences. Oregon Review of International Law, 10(2), 327-360.

GAURI, Varun, and BRINKS, Daniel (eds.). (2008) Courting Social Justice: Judicial Enforcement of Social and Economic Rights in the Developing World (New York: Cambridge University Press). 
GISSELQUIST, Rachel. (2012) Good governance as a concept, and why this matters for development policy. United Nations University - World Institute for Development Economics Research, 1-36.

GO, Julian. (2010) Modeling state and sovereignty: Postcolonial constitutions in Asia and Africa. In Making a World after Empire: The Bandung Movement and its Political Afterlives, Christopher Lee (ed.) (Athens: Ohio University Press).

GUTTO, Shadrack. (2006) The right to development: An implied right in South Africa's constitutional order. In SAHRC Reflections on Democracy and Human Rights: A Decade of the South African Constitution (Act 108 of 1996) (Johannesburg: South African Human Rights Commission)

HEIDHUES, Franz, and OBARE, Gideon. (2011) Lessons from structural adjustment programmes and their effects in Africa. Quarterly Journal of International Agriculture, 50(1), 55-64.

HELDRING, Leander, and ROBINSON, James. (2012) Colonialism and economic development in Africa. National Bureau of Economic Research-Working Paper 18566, 1-40.

HRITULEAC, Alexander. (2011) The Effects of Colonialism on African Economic Development: A Comparative Analysis Between Ethiopia, Senegal and Uganda. MSc dissertation, Aarhus University.

KAMGA, Serges. (2011) Human Rights in Africa: Prospects for the Realisation of the Right to Development Under the New Partnership for Africa's Development. LLD thesis, University of Pretoria.

KINDORNAY, Shannon, RON, James, and CARPENTER, Charli. (2012) Rights-based approaches to development: Implications for NGOs. Human Rights Quarterly, 34(2), 472-506.

KINGSTON, Christina, IRIKANA, Godspower, NDIENYE, Victory, and KINGSTON, Kato Gogo. (2011) The impacts of the World Bank and IMF structural adjustment programs on Africa: The case study of Cote D'Ivoire, Senegal, Uganda, and Zimbabwe. Sasha Journal of Policy and Strategic Studies, 1(2), 110-130.

KIRCHMEIER, Felix. (2006) The right to development - Where do we stand?: State of the debate on the right to development. Friedrich Ebert Stiftung Occasional Paper No. 23, 1-28.

KIRCHMEIER, Felix, LÜKE, Monika, and KALLA, Britt. (2008) Towards the Implementation of the Right to Development (Geneva: Friedrich-Ebert-Stiftung).

LAWYERS COMMITTEE FOR HUMAN RIGHTS. (1995) The World Bank: Governance and Human Rights, 2nd ed. (New York: Lawyers Committee for Human Rights).

LOGAN, Fraser. (2015, January) Did Structural Adjustment Programmes Assist African Development? [Online]. Available: http://www.e-ir.info/2015/01/13/did-structural-adjustment-programmes-assist-african-development/ [4 May 2016].

M’BAYE, Kéba. (1972) Le droit au développement comme un droit de l’homme: Leçon inaugural de la troisième session d'enseignement de l'Institut International des Droits de l'Homme. Revue des Droits de l'Homme, 5, 505-534.

MAHALU, Costa. (2009) Human rights and development: An African perspective. Leiden Journal of International Law, 1 (1), 15-24.

MALDONADO, Nicole. (2010, May) The World Bank's Evolving Concept of Good Governance and its Impact on Human Rights. Paper presented at the Doctoral Workshop on Development and International Organisations, Stockholm, Sweden.

MELBER, Henning (ed.). (2012) No Future without Justice: Report of the Civil Society Reflection Group on Global Development Perspectives, Development Dialogue No. 59. (Uppsala: Dag Hammarskjöld Foundation).

MURRAY, Rachel. (2004) Human Rights in Africa: From the OAU to the African Union (Cambridge: Cambridge University Press).

NAGAN, Winston. (2013) The right to development: Importance of human and social capital as human rights issues. Cadmus Journal, 1(6), 24-48.

NEPAD PLANNING AND COORDINATING AGENCY. (2015) Blueprint for an Integrated Approach to Implement Agenda 2063 (Midrand: New Partnership for Africa's Development).

NEW PARTNERSHIP FOR AFRICA'S DEVELOPMENT (NEPAD). (2001, July) NEPAD Declaration adopted at the 37th session of the Assembly of Heads of State and Government, Lusaka.

NKRUMAH, Kwame. (1963) Africa Must Unite (New York: Frederick Praeger Publisher).

NUNN, Nathan. (2005) Slavery, institutional development and long-term growth in Africa, 1400-2000. Journal of Economic Literature. [Online] Available: http://scholar.harvard.edu/files/nunn/files/the_long_term_effects.pdf [4 June 2016].

NUNN, Nathan. (2007) The historical origins of Africa's underdevelopment. VOX CEPR's Policy Portal. [Online]. Available: http://www.voxeu.org/article/slave-trade-and-african-underdevelopment [13 February 2016].

NUNN, Nathan. (2008) The long-term effects of Africa's slave trades. Quarterly Journal of Economics, 123(1), $139-176$.

ODUTAYO, Aramide. (2015) Conditional Development: Ghana Crippled by Structural Adjustment Programmes. [Online]. Available: http://www.e-ir.info/2015/03/01/conditional-development-ghana-crippled-by-structural-adjust ment-programmes/ [4 May 2016].

ODUWOLE, Olajumoke. (2014) International law and the right to development: A pragmatic approach for Africa. International Institute of Social Studies. [Online]. Available:www.iss.nl/fileadmin/ASSETS/iss/Documents/Academic_publi cations/PCC_Inaugural_Lecture_20May2014.pdf [4 June 2016].

OLOKA-ONYANGO, Joe. (1999) Heretical reflections on the right to self-determination: Prospects and problems for a democratic global future in the new millennium. American University International Law Review, 15(1), 151-208.

ORGANISATION OF AFRICAN UNITY. (1981, June) African Charter on Human and Peoples' Rights adopted in Nairobi on 27 June 1981. OAU Doc. CAB/LEG/67/3 rev. 5, 21 I.L.M. 58. 
OUguergouZ, Fatsah. (2003) The African Charter on Human and Peoples' Rights: A Comprehensive Agenda for Human Dignity and Sustainable Democracy in Africa (Netherlands: Martinus Nijhoff Publishers).

ÖZDEN, Melik, and GOLAY, Christophe. (2010) The Right of Peoples to Self-Determination and to Permanent Sovereignty over their Natural Resources Seen from a Human Rights Perspective. [Online]. Available: http://www.cetim.ch/ legacy/en/documents/bro12-auto1-A4-an.pdf. [4 June 2016].

PRADOS de la ESCOSURA, Leandro. (2011) Human development in Africa: A long-run perspective. University Carlos III de Madrid. Working Papers in Economic History WP 11-09. [Online]. Available: http://e-archivo.uc3m.es/bit stream/handle/10016/12087/wp\%2011_09.pdf;jsessionid=F2A1F4FE7CFF45B488B07A2D34017417?sequence=5 [4 June 2016].

RAJAGOPAL, Balakrishnan. (2013) Right to development and global governance: Old and new challenges twenty-five years on. Human Rights Quarterly, 35(4), 893-909.

RONO, Joseph. (2002) The impact of the structural adjustment programmes on Kenyan society. Journal on Social Development in Africa, 17(1), 81-98.

SENGUPTA, Arjun. (2000) Realizing the right to development. Development and Change, 31(3), 553-578.

SENGUPTA, Arjun. (2002) On the theory and practice of the right to development. Human Rights Quarterly, 24(4), 837-889.

SENGUPTA, Arjun. (2003, December) Development cooperation and the right to development. 1-25.

SING'OEI, Korir. (2013) Engaging the leviathan: National development, corporate globalisation and the Endorois quest to recover their herding grounds. In The Interrelation Between the Right to Identity of Minorities and their Socio-Economic Participation, Kristin Henrard (ed.) (Leiden: Martinus Nijhoff Publishers).

ŠLAUS, Ivo, and JACOBS, Garry. (2013) In search of a new paradigm for global development. Cadmus Journal, 1(6), 1-7.

THOMSON, Alex. (2010) An Introduction to African Politics, 3rd ed. (New York: Taylor and Francis).

TRANSPARENCY INTERNATIONAL. (2015) Corruption on the Rise in Africa Poll as Governments Seen Failing to Stop it. [Online]. Available: http://www.transparency.org/news/pressrelease/corruption_on_the_rise_in_africa_poll_as_go vernments_seen_failing_to_stop_i [4 May 2016].

UNITED NATIONS. (1945) Charter of the United Nations. UN Doc. 59 Stat. 1031: TS 993: 3 Bevans 1153.

UNITED NATIONS. (1948) Universal Declaration of Human Rights. General Assembly Resolution 217 A (III). UN Doc $\mathrm{A} / 810$ at $71(1948)$.

UNITED NATIONS. (1966) International Covenant on Economic, Social and Cultural Rights. General Assembly Res. 2200A (XXI), 21 UN GAOR Supp. (No. 16) at 49, UN Doc. A/6316 (1966); 993 UNTS 3; 6 ILM 368 (1967).

UNITED NATIONS. (1986) Declaration on the Right to Development General. Assembly Resolution 41/128.UN GAOR, 41st Sess., Supp. No. 53, UN Doc. A/RES/41/128 (1986) 186.

UNITED NATIONS. (1992) Rio Declaration on Environment and Development adopted at the UN Conference on Environment and Development, Rio de Janeiro 3-14 June 1992.

UNITED NATIONS. (1993) Vienna Declaration and Program of Action adopted at the UN World Conference on Human Rights, UN Doc. A/CONF.157/24, 25 June 1993.

UNITED NATIONS. (2000) Millennium Declaration, adopted by the General Assembly Resolution A/55/L.2, 8 September 2000 .

UNITED NATIONS. (2001) Durban Declaration and Program of Action adopted at the World Conference against Racism, Racial Discrimination, Xenophobia and Related Intolerance Declaration, Durban, South Africa, 31 August - 8 September 2001.

UNITED NATIONS. (2007) Declaration on the Rights of Indigenous Peoples adopted by General Assembly Resolution 61/295 on 13 September 2007. UN Doc. A/61/L.67.

UNITED NATIONS DEVELOPMENT GROUP. (2003) The human rights based approach to development cooperation: Towards a common understanding among UN Agencies, UNDG Documents Guidance and Policies.

UNITED NATIONS HUMAN RIGHTS. (2013) Realizing the Right to Development. (Geneva and New York: United Nations Publication).

WHATLEY, Warren, and GILLEZEAU, Rob. (2009) The Impact of the Slave Trade on African Economies (Michigan: Department of Economics, University of Michigan). [Online]. Available: http://www-personal.umich.edu/ baileymj/Whatley_Gillezeau. pdf [4 June 2016].

WORLD BANK. (2000) Can Africa Claim the 21 ${ }^{\text {st }}$ Century? (Washington, DC: The International Bank for Reconstruction and Development/The World Bank). 